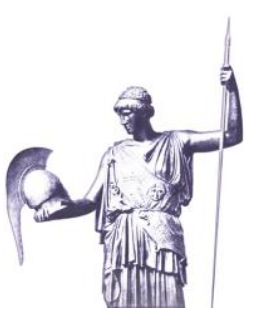

Research Article
Connections: The Quarterly Journal

ISSN 1812-1098, e-ISSN 1812-2973

V. Shalamanov, P. Anastasov \& G. Tsvetkov

Connections QJ 18, no. 1-2 (2019): 25-42

https://doi.org/10.11610/Connections.18.1-2.02

\title{
Deterrence and Defense at the Eastern Flank of NATO and the EU: Readiness and Interoperability in the Context of Forward Presence
}

\author{
Velizar Shalamanov, ${ }^{1}$ Pavel Anastasov, ${ }^{2}$ \\ and Georgi Tsvetkov ${ }^{3}$
}

1 Institute of ICT, Bulgarian Academy of Sciences, http://www.iict.bas.bg/EN

2 Political Affairs and Security Policy Division, NATO International Staff

3 “G. S. Rakovski" National Defence College, Sofia, https://rndc.bg/en/

\begin{abstract}
This article reflects the discussions during a September 2018 conference in Sofia, sponsored by the NATO Public Diplomacy Division. Its focus is on the defense and deterrence posture of NATO and the European Union in Eastern Europe. Special attention is given to the development of the Bucharest Initiative (B9) and its influence on the Western Balkans and Black Sea Region. The authors propose a Program for Readiness and Interoperability, oriented to the C4ISR area. This is based on the defense posture and in the context of the developments in NATO and the European Union for improved readiness and interoperability with partners that, together with enhanced cooperation in education and training for the defined B9+ region, will act as instruments to implement this cooperation and improve the deterrence and defense capability on the Eastern Flank of NATO and the EU, while at the same time strengthening resilience to hybrid threats.
\end{abstract}

Keywords: NATO, European Union, defense, deterrence, readiness, interoperability, cooperation, Eastern flank, Balkans, Black Sea region, resilience. 


\section{NATO Presence in Eastern Europe after the Changes of $1989^{1}$}

The elaboration in this article is based on developments of multinational formations in Central and Eastern Europe (CEE)/South Eastern Europe (SEE), improving their interoperability and readiness through multinational projects, especially in the area of Communications and Information (C\&I), and adequate education and training, including exercises. Further research is proposed in a multinational format to define programs for the readiness and interoperability of multinational formations in CEE/SEE.

After the changes in 1989, NATO was seriously involved in Eastern Europe, and a visible presence of military formations began in 1995 with the responsibility to the United Nations (UN) for carrying out the Dayton Peace Accords. This agreement was signed on November 22, 1995 by the presidents of Bosnia, Croatia, and Serbia, on behalf of Serbia and the Bosnian Serb Republic. The actual signing took place in Paris on December 14, 1995. The accords had three major goals: the ending of hostilities, the authorization of military and civilian programs, and the establishment of a central Bosnian government while excluding war criminals from taking part in the running of the government. The first NATOled multinational force (IFOR) was established to implement the military Annexes of The General Framework Agreement for Peace (GFAP) in Bosnia and Herzegovina.

IFOR relieved the UN peacekeeping force (UNPROFOR), which had originally arrived in 1992, and the transfer of authority was agreed upon in Security Council Resolution 1031. Almost 60,000 NATO soldiers, in addition to forces from nonNATO nations, were deployed to Bosnia. Operation Decisive Endeavor (SACEUR OPLAN 40105) that began on December 6, 1995, was a subcomponent of Joint Endeavor.

The next large multinational presence was SFOR which was established by Security Council Resolution 1088 on December 12, 1996, to succeed IFOR. Troop levels were reduced to approximately 12,000 by the close of 2002 , and to approximately 7,000 by the close of 2004 when, at the Istanbul Summit of NATO, the end of the mission was announced.

Operation Althea, formally European Union Force (EUFOR) in Bosnia and Herzegovina, is the successor to SFOR/IFOR. The transition from SFOR to EUFOR was largely a change of name and commanders: $80 \%$ of the troops remained in place. Formally, it replaced SFOR on December 2, 2004.

KFOR was the next large multinational deployment in Eastern Europe after NATO's first actual combat operation in Europe. ${ }^{2}$ Following the adoption of UN Security Council Resolution 1244, troops entered Kosovo on June 11, 1999. At the time, Kosovo was facing a grave humanitarian crisis with nearly one million

1 This section draws extensively on information posted on the NATO web site, https://www.nato.int, and the English version of Wikipedia.

2 Gen. Wesley K. Clark, Waging Modern War: Bosnia, Kosovo and the Future of Combat (New York: Public Affairs, 2001). 
people displaced as refugees. At its height, KFOR troops numbered 50,000 and came from 39 different NATO and non-NATO nations.

KFOR, during the years, has gradually transferred responsibilities to the Kosovo Security Forces and other local authorities and, as of May 23, 2016, consisted of 4,600 troops. Recently, the Kosovo Force in Pristina (2018) consisted of: Headquarters Support Group (HSG), in Pristina; Multinational Specialized Unit (MSU), in Pristina (a Military Police regiment composed entirely of Italian Carabinieri); Multinational Battle Group-East (MNBG-E) at Camp Bondsteel near Ferizaj (a US Army force supported by Hungary, Poland, Romania, and Turkey); Multinational Battle Group-West (MMBG-W) at Camp Villaggio Italia near Peć (an Italian Army force supported by Austria, Moldova, and Slovenia); Joint Logistics Support Group (JLSG) in Pristina (Logistics and engineering support); KFOR Tactical Reserve Battalion (KTRBN) at Camp Novo Selo (Composed entirely of Hungarian Army troops); Joint Regional Detachment - North (JRD-N) at Camp Novo Selo (local non-kinetic liaison and monitoring); Joint Regional Detachment-Centre (JRD-C) in Pristina (local non-kinetic liaison and monitoring); Joint Regional Detachment - South (JRD-S) in Prizren (Local non-kinetic liaison and monitoring).

Experience gained in the Balkans was essential in defining the crisis management and the use of multinational formations down to the tactical level. Acting outside of Europe, ISAF was a multinational force of critical importance for the development of the concept of interoperability, especially with the introduction of the Afghanistan Mission Network (AMN) as an operational tool. ${ }^{3}$

The next large operation-Unified Protector-was a challenge while at the same time an opportunity to test readiness and interoperability in Air and Maritime domains. ${ }^{4}$ The crisis management challenge from an operational perspective was addressed through a number of different initiatives that included a Complex Crisis Operations Management Center (CCOMC) to provide situational awareness and support further planning with the available ready and interoperable forces, which were, as a rule, multinational formations. ${ }^{5}$

The transition from crisis management was most visible at the Wales Summit in 2014 when the NATO allies agreed to implement the Readiness Action Plan (RAP) in order to respond swiftly to the fundamental changes in the security environment on NATO's Eastern borders.

Building on the RAP, the Allies took further decisions at the Warsaw Summit in 2016 to strengthen NATO's deterrence and defense posture and to contribute to projecting stability and strengthening security outside of Alliance territory. Together, these decisions were the biggest reinforcement of Alliance collective defense in a generation. Combined with the forces and capabilities required for

3 Gen. Stanley McChrystal, My Share of the Task: A Memoir (New York: Penguin Publishing Group, 2013).

4 Rob Weighill and Florence Caub, The Cauldron: NATO's Campaign in Libya (London: Hurst Publishers, 2018).

5 James Stavridis, The Accidental Admiral: A Sailor Takes Command at NATO (Annapolis, Maryland: Naval Institute Press, October 2014). 
rapid reinforcement by follow-on forces, these measures will enhance the security of all Allies and ensure the protection of Alliance territory, populations, airspace, and sea lines of communication, including across the Atlantic, against threats from wherever they arise.

NATO's enhanced forward presence is defensive, proportionate, and in line with international commitments. It represents a significant commitment by Allies and is a tangible reminder that an attack on one is an attack on all.

Fully deployed in June 2017, NATO's enhanced forward presence comprises multinational forces provided by framework nations and other contributing Allies on a voluntary, fully sustainable, and rotational basis. They are based on four rotational, battalion-size battlegroups that operate in concert with national home defense forces and are present at all times in the host countries. Canada, Germany, the United Kingdom, and the United States are the framework nations for this robust multinational presence in Latvia, Lithuania, Estonia, and Poland, respectively.

Other Allies have confirmed contributions to these forces: Albania, the Czech Republic, Italy, Poland, Slovakia, Slovenia, and Spain contribute to the Canadianled battlegroup in Latvia; Belgium, the Czech Republic, Iceland, Luxembourg, the Netherlands, and Norway have joined the German-led battlegroup in Lithuania; Denmark and Iceland contribute to the UK-led battlegroup in Estonia; and Croatia, Romania, and the United Kingdom have joined the US-led battlegroup in Poland. These enhanced forward presence forces are complemented by the necessary logistics and infrastructure to support pre-positioning and to facilitate rapid reinforcement. The four battlegroups are under NATO command through the Multinational Corps Northeast Headquarters in Szczecin, Poland. These four battlegroups' training and preparation activities are coordinated and supervised by the Multinational Division Northeast Headquarters (MND-NE) in Elblag, Poland.

At the 2016 Summit in Warsaw, the Allies also agreed to develop a tailored forward presence in the south-eastern part of Alliance territory. On land, this presence is built around the Romanian-led multinational brigade in Craiova. In the air, several Allies have reinforced Romanian and Bulgarian efforts to protect NATO airspace. This means more NATO forces and more exercises and training under the Headquarters Multinational Division Southeast (in Romania), which became fully operational in June 2017. This tailored forward presence contributes to the Alliance's strengthened deterrence and defense posture and to its situational awareness, interoperability, and responsiveness.

All these changes are in response to Russia's aggressive behavior since 2008, but the turning point was really the annexation of Crimea and the aggressive actions in Eastern Ukraine, together with the development of the hybrid warfare concept and its implementation. It means that to the East NATO faces the Rus- 
sian hybrid challenge, ${ }^{6}$ but, at the same time, a very real Russian conventional challenge. ${ }^{7}$

NATO's rapid reinforcement strategy also ensures that forward presence forces will, if necessary, be reinforced by NATO's Very High Readiness Joint Task Force, the broader NATO Response Force, the Allies' additional high readiness forces and NATO's heavier follow-on forces. NATO is also developing several additional measures to increase its presence in the Black Sea region. Specific measures for a strengthened NATO maritime and air presence in the region are being implemented, with several Allies contributing forces and capabilities. Though the forward presence is mostly focused in North-Eastern Europe, the geostrategic importance of the Black Sea is growing, ${ }^{8}$ especially for Russia after the annexation of Crimea, and as a result, there is a visible confrontation between Russia and $\mathrm{NATO}^{9}$ in the region.

Based on this short review of the development of multinational forces for crisis management as well as for deterrence and defense, the remainder of the article explores the potential in CEE after NATO's Brussels Summit (2018) with related opportunities to improve readiness and interoperability through multinational communications and information projects and adequate training.

\section{The Deterrent Potential of the Alliance in Its Eastern Area of Responsibility - the Way Ahead}

The Alliance's Eastern area of responsibility and the Black Sea Region continues to be one of the most dynamic regions with some of the greatest security challenges. They all stem from Russia's aggressive posture in the East, the South of Europe, and the Western Balkans. After the Brussels Summit, at the NATO sponsored international conference in Sofia, Bulgaria in 2018, the special panel on deterrence and defense posture in Eastern Europe agreed that out of the three main tasks of collective defense, crisis management, and cooperative security, collective defense remains the key focus with steady and fast evolution through

6 Franklin D. Kramer and Lauren M. Speranza, "Meeting the Russian Hybrid Challenge: A Comprehensive Strategic Framework" (Washington, DC: Atlantic Council, Brent Scowcroft Center on International Security, May 2017), https://www.atlanticcouncil.org/indepth-research-reports/report/meeting-the-russian-hybrid-challenge.

7 Franklin D. Kramer and Hans Binnendijk, "Meeting the Russian Conventional Challenge: Effective Deterrence by Prompt Reinforcement" (Washington, DC: Atlantic Council, Brent Scowcroft Center on International Security, February 2018), www.atlantic council.org/in-depth-research-reports/report/meeting-the-russian-conventionalchallenge.

8 Bouris Toucas, The Geostrategic Importance of the Black Sea Region: A Brief History, Center for Strategic and International Studies (CSIS), February 2, 2017, www.csis.org/analysis/geostrategic-importance-black-sea-region-brief-history.

9 Boris Toucas, NATO and Russia in the Black Sea: A New Confrontation? Center for Strategic and International Studies (CSIS), March 6, 2017, available at https://www.csis.org/analysis/nato-and-russia-black-sea-new-confrontation. 
the summits in Wales, Warsaw, and Brussels. This evolution was described as moving from a posture of deterrence by punishment to one of deterrence by denial. New decisions raised at the Brussels Summit, such as the NATO Readiness Initiative, but also the current development of forward presence measures together with the US European Defense Initiative (EDI), have reaffirmed the steadfast commitment of NATO to collective defense and of the US to European defense.

NATO Eastern flank representatives at the conference gave priority to further development of the deterrence by denial scenario with a focus on the role of the Bucharest 9 (B9) format of cooperation to become the voice of CEE. ${ }^{10}$ The Alliance must continue to focus its efforts on improving expanded military capabilities in order to demonstrate a credible ability to oppose aggression from the first instance. The focus within the NATO core task should be on advanced planning, military mobility within the Alliance, and initiatives for readiness with forward presence and improved interoperability in the multinational environment on the tactical level. In greater detail, this deterrent capability requires (1) improved early warning systems to allow the Alliance more time to react, (2) credible national forces capable of waging initial defense, and (3) enhanced mobility and pre-positioned equipment to enable that broad Alliance response.

One important element is the firm understanding that NATO adaptation and European Union (EU) developments in the defense area should be fully synchronized. The advantages of the EU defense industrial complex and developing defense research programs, the tools available to the European External Action Service, and the development of the PESCO projects should all be in line with NATO developments and are complementary to one another while making both NATO and EU stronger and safer. The European Union should continue making the best use of NATO defense policy and planning methodology. Good coordination between NATO and the EU headline goal process and capability development plan is a must.

Bulgaria, Romania, and Turkey are the main stakeholders in the development and implementation of the current NATO Tailored Forward Presence measures. These measures build up the Alliance deterrence and defense posture in the Black Sea Region and have to be fully synchronized with the security of the North East/Baltic Region of Eastern Europe (Baltic States, Visegrad Group) linked with the Western Balkans and Adriatic Sea. The multinational brigade in Craiova, with Romania as a framework nation, is the main element of the land component. In the air domain, the Allies are reinforcing the efforts of Romania and Bulgaria for air policing. In the maritime domain, standing NATO maritime forces are present with more ships and more naval exercises in the region. A Black Sea Functional

10 Marcin Terlikowski, with Veronika Jóźwiak, Łukasz Ogrodnik, Jakub Pieńkowski, and Kinga Raś, "The Bucharest 9: Delivering on the Promise to Become the Voice of the Eastern Flank," PISM Policy Paper no. 4 (164) (Warsaw: Polish Institute of International Affairs, 2018), accessed October 29, 2018, http://www.pism.pl/Publications/PISMPolicy-Paper-no-164. 
Centre has been established within the NATO Maritime Command. A new enhanced training initiative aims to bring more coherence in all training efforts in the region. Generally, all tailored measures should ensure readiness and interoperability.

Seen as strictly military-technical issues prior to the Wales Summit, now readiness and interoperability are becoming the key criteria for the effectiveness of NATO's adaptation to the Russian conventional challenge. And this is where the Allies will need to show resolve since both readiness and interoperability cost a lot. The need for being innovative and thinking of cost-effective options should be explored and developed in order to demonstrate credible deterrence. This includes more rotations for exercises, cross-border air training (which might be based on the NORDEFCO model), a maritime presence (on both Baltic and Black Seas), and more permanent stationing.

Bulgaria must work to ensure a real and continuous presence of Allied forces on its territory by hosting land, air, and naval components of the NATO Forward Presence such as hosting:

- a coordination element of the Allied Maritime Command in Varna, connected with the NATO Force Integration Units (NFIUs) in Sofia and Bucharest;

- a multinational Air Force fighter squadron on a rotational basis, in a Bulgarian military airbase (especially during the period of acquiring a new fighter and potentially accelerating the outgoing of the MiG-29) that should carry out joint allied air policing of the Bulgarian airspace, potentially to cover the airspace of North Macedonia after finalizing the accession process (in cooperation with Greece and other Allies);

- a multinational mechanized brigade or a multinational Special Operations brigade, with Bulgaria being the framework nation.

As an expression of solidarity and cohesion along the whole Eastern Flank, Bulgaria must join one of the established four NATO multinational battlegroups in the Baltic states and Poland.

The new Readiness Initiative, agreed at the Brussels Summit, should improve NATO's ability to mobilize and deploy larger reinforcements and hence enhance deterrence and defense on the Alliance's Eastern Flank. The initiative should ensure that more high-quality, combat-capable national forces at high readiness can be made available to NATO. From within the overall pool of forces, the Allies will offer an additional 30 major naval combatants, 30 heavy or medium maneuver battalions, and 30 kinetic air squadrons, with enabling forces, at no more than 30 days' readiness. They will be organized and trained as elements of larger combat formations in support of NATO's overall deterrence and defense posture. As stated in the Summit Communique, the Readiness Initiative will further enhance the Alliance's rapid response capability, either for the reinforcement of Allies in support of deterrence or collective defense, including for high-intensity warfighting, or for rapid military crisis intervention, if required. It will also pro- 
mote the importance of effective combined arms and joint operations. Being the logical evolution after the Wales Summit, the Readiness Action Plan, and the Warsaw Summit focus on Forward Presence, this new initiative, as ambitious and important as it might be, could face a lot of challenges in its implementation.

A number of areas will need special attention because increasing and maintaining forces' readiness involves high costs. The 30 days target will also need to be further discussed, given Russia's regional superiority in land forces. For countries like Bulgaria, in addition to the challenges of providing trained and equipped units, the ability to provide host nation support and mobility needs to be considered urgently by the national authorities. Bearing in mind that the acquisition of the new NATO interoperable fighters and ships in Bulgaria was postponed in 2014, the most obvious contribution would be a mechanized battalion. Working closely with Albania, Montenegro and, soon, North Macedonia, it will be possible to contribute to the Readiness Initiative with regional multinational battalions dedicated to NATO that will facilitate interoperability and readiness.

It is important, also, to consider the efforts of both NATO and the EU to improve military mobility by land, air, and sea, their tackling of the related physical barriers such as deficiencies in infrastructure and its incompatibility with military requirements, as well as the shortages in means of transportation. In addition, the need for tackling procedural obstacles, such as the time for national permission for a border crossing by forces and equipment, must also be addressed.

The Brussels Summit reconfirmed the commitment to the Defense investment pledge of the 2014 Wales Summit. Fair burden-sharing underpins the Alliance's cohesion, solidarity, credibility, and the ability to fulfill Article 3 and Article 5 commitments. Allies have started to increase the amount they spend on defense in real terms and two-thirds of the Allies have national plans in place to spend $2 \%$ of their Gross Domestic Product on defense by 2024 . More than half of them are allocating more than $20 \%$ of their defense expenditures on major equipment, including related research and development, and, according to their national plans, 24 Allies will meet the $20 \%$ guideline by 2024 .

Bulgaria must review and adapt its government plans to commit to reaching the level of defense spending of $2 \%$ of the GDP in 2020, instead of in 2024. They must also plan to attain a level of spending on new capabilities and research of at least $20 \%$ of the total defense spending (and potentially to identify a model for increased defense spending above these levels during the early stages of rearmament in order to accelerate the replacement of old, non-interoperable and often risky-to-operate Soviet equipment). This should be in line with reaching an agreement on the setting of a deadline for the termination of member states' dependence on the Russian Federation for the maintenance of major weapon systems and equipment, including, by way of enhanced cooperation, in the framework of NATO and the EU.

An additional national measure to be considered here is the establishment of an Armaments Acquisition Agency that must be created with clearly defined roles, responsibilities, and tasks, in accordance with the principles of democracy 
and good governance. This should include project management mechanisms and close coordination with NATO and European armaments and acquisition agencies. Within its mandate, it must work towards finding synergies within its joint acquisition and maintenance capabilities with NATO Allies/EU Member states in the Western Balkans, the Black Sea Region and beyond.

Further, as Laura Brent pointed out in a recent article in NATO Review, "Cyber threats to the security of the Alliance are becoming more frequent, coercive, complex, and destructive." ${ }^{11}$ Cyber defense is part of NATO's core task of collective defense. Bulgaria must be able to operate as effectively in cyberspace as it does in the air, on land, and at sea to strengthen and support the Alliance's overall deterrence and defense posture. Therefore, Bilgaria can provide an important contributin toe deterrence and defense by delivering a strong national cyber defense through the full implementation of the Cyber Defense Pledge, which is central to enhancing cyber resilience and raising the costs of a cyber-attack.

A suggested measure for Bulgaria is creating a cyber and hybrid threats response center under the Ministry of Defense with tasks to investigate, analyze, and then coordinate and implement measures to counter cyber and hybrid threats. This center must be linked with NATO HQ capabilities for early warning as well as with the relevant Centers of Excellence in the NATO and EU framework. The development of new regulations in the EU on the set-up of a European cybersecurity industrial, technology and research competence with a network of national coordination centers calls for close coordination with defense area developments on a national level and respectively with NATO.

Together with good NATO/EU cooperation, regional cooperation is a critical dimension of success. The group of nations most concerned with the deterrence and defense of NATO's Eastern Flank could be defined as Bucharest 9+/B9+ (the Eastern Flank Allies which are Poland, the three Baltic States, Hungary, Czech Republic, Slovakia, Romania, Bulgaria, but also Albania, Montenegro, and Croatia, with North Macedonia as a future member state). This format could actively engage with key NATO partners such as Georgia and Ukraine. These two partners have continuously stated that they welcome Alliance efforts to provide a credible defense on its Eastern Flank and to continue its commitment to maintaining stability in the wider Black Sea Region. A good example of a similar relationship is between Sweden and Finland (EU, but not NATO members) who are actively engaged in projecting stability in the Baltic Sea Region.

Following the best practices from NORDEFCO and BENELUX, project-based cooperation in the B9 format must continue to be developed. The initiation of a flagship Program for Readiness and Interoperability (PRI) in this context, as defined below, could be the first step for change. There is a great potential for integration through exercises and real operations for a number of national and multinational formations in the region. Following the example of the "NATO First

11 Laura Brent, "NATO's Role in Cyberspace," NATO Review, 12 February 2019, https://www.nato.int/docu/review/articles/2019/02/12/natos-role-in-

cyberspace/index.html. 
Solution" used for NATO Force Structure HQs, PRI could be fully supported by the NATO Communications and Information Agency (NCIA) and the NATO Support and Procurement Agency (NSPA). Regional projects for air and maritime surveillance are potential pilot projects to follow and a joint review of other procurement/ logistics in the B9+ format could provide a solid base for the portfolio of multinational projects to procure equipment or at least to have regional maintenance and overhaul systems with NSPA support.

\section{The Development of Interoperability and Readiness Initiatives in NATO}

The roots of change began at the Prague Summit in November 2002, when NATO recognized that the transformation of the military based upon the Information Age principles was essential. A course of transformation following the concept of NATO Network-Enabled Capabilities (NNEC) was then pursued. All operations in the Balkans ${ }^{12}$ (Bosnia and Herzegovina, Kosovo), with a presence in Albania and Macedonia as well, provided so much experience that it provoked a transformational endeavor in NATO with the turning point based on ISAF ${ }^{13}$ and OUP. ${ }^{14}$ Recently the implementation of RAP and the new Readiness Initiative are providing further impetus to these efforts.

A good example, in 2003, was how nine NATO nations (Canada, France, Germany, Italy, the Netherlands, Norway, Spain, the United Kingdom, and the United States) arranged to fund a feasibility study on NNEC. This study was assigned to the NATO C3 Agency (NC3A), and later, the ACT launched an awareness campaign to promote the NNEC concept based on the results of the study. At the same time, the NNEC Program office was established in NC3A to manage all NNEC related common funded projects. Achieving full collaboration and full coherence between the various projects of NATO and NATO Nations is the longterm goal, so in 2009 the Agency formed a new sponsor account "NATO and Nations" to support the implementation of the C4ISR projects outside the NATO Command structure, related to interoperability in the C\&I domain.

The NNEC program aimed at producing a federation of capabilities at all levels, military (strategic to tactical) and civilian, through an information infrastructure and, at the same time, following the vision of "Share to Win," started work on a culture change for the people involved. Information sharing is the precondition for better situational awareness and faster decision-making that improves collaboration between nations which, ultimately, saves lives and resources. The information infrastructure is the supporting base that enables collaboration and information sharing amongst users and reduces the decision-cycle time. This

\footnotetext{
12 Clark, Waging Modern War.

${ }^{13}$ McChrystal, My Share of the Task.

14 Weighill and Caub, The Cauldron.
} 
leads to information superiority, ${ }_{15}^{15}$ which is the ability to get the right information to the right people at the right time.

In 2009, the NATO Consultation, Command and Control Agency (NC3A) recognized the growing demand to support nations in addition to NATO common funded C4ISR (command, control, communications, computers, intelligence, surveillance, and reconnaissance) programs in the development of modern, interoperable and secure C4ISR capabilities. So, the Agency proposed on November 11, 2009, the NATO Comprehensive Approach ${ }^{16}$ to C4ISR to the NC3 Board for notation.

The C4ISR/Cyber domain in the context of Federated Mission Networking (FMN) plays a central role in force integration. In order to accelerate the development in this area, especially for Eastern European NATO members and partners in NC3A (now NCIA), the establishment of a C4ISR Integration Fund ${ }^{17}$ was proposed in 2010. The implementation of this model started in 2014 with the C4 Trust Fund for Ukraine led by Canada, UK, and Germany and supported by NCIA.

To a great extent, the Agency Reform initiative for the C4ISR area, approved at the Lisbon Summit in 2010, was endorsing the NATO Comprehensive Approach to C4ISR. It provided support for the whole security sector, going outside the defense establishment to include other partners. It also covered the whole life cycle of C4ISR capabilities from requirements definition to deployment and even decommissioning. Furthermore, it used all available funding sources from common funding through multinational and trust fund-based funding to individual nations funding.

In the C4ISR area, this comprehensive approach provided a basis for "Smart Defense" for capability development and service provision by modeling this area even before its announcement as a flagship NATO initiative at the Chicago Summit in May 2012. There, NATO leaders agreed to embrace Smart Defense ${ }^{18}$ to ensure that the Alliance could develop, acquire and maintain the capabilities required to achieve the goals of "NATO Forces 2020 " of modern, tightly connected forces that are properly equipped, trained, exercised, and led.

In the NATO Executive Development Program (NEDP) cycle of 2013/2014 the two principal NATO agencies asked young leaders in NATO to explore Multina-

15 NATO defines information superiority as the operational advantage derived from the ability to collect, process, and disseminate an uninterrupted flow of information while exploiting or denying an adversary's ability to do the same.

${ }^{16}$ NATO C4ISR Comprehensive Approach (Brussels: NATO C3 Board and NC3A, 11 November 2009).

17 "Establishment of a C4ISR Integration Fund" (Brussels: NC3A, 2010).

18 The new approach to defense spending during tight economic times-Smartf Defense-was defined by SecGen Mr. Rasmussen as "ensuring greater security, for less money, by working together with more flexibility." As part of this approach, he advocated for nations to "pool and share capabilities, to set the right priorities, and to better coordinate our efforts." 
tional Cooperation ${ }^{19}$ facilitated by the $\mathrm{NCl}$ Agency and NSPA. In the 2015/2016 cycle of NEDP, the Defense Investment division used the same mechanism to assess Smart Defense five years in the future. ${ }^{20}$

As an element of Smart Defense in the $\mathrm{NCl}$ Agency, an approach was developed to support nations in re-using NATO common funded solutions for faster, born-interoperable, and secure solutions in the area of C4ISR. This initiative was presented at the annual $\mathrm{ClO}$ conference in NATO as a program "NATO for Nations" to support the Smart Defense and Connected Forces initiatives of the NATO Secretary General. This program's implementation is based on the "NATO First" solution offered to Nations through the Agency Catalogue. ${ }^{21}$

Again, the Agency decided to benefit from the NEDP class of 2015/2016 and initiated a study on the implementation of the "NATO First" solution ${ }^{22}$ in support of Smart Defense and Connected Forces initiatives. Initially, the main driver for the development of the "NATO First" solution for NATO Force Structure (NFS) ${ }^{23}$ was the Afghanistan Mission Network (AMN) initiative in response to the request by General McChrystal to have one Command and Control (C2) network for ISAF in 2009. ${ }^{24}$

The decisions made at the Wales Summit to establish the Readiness Action Plan (RAP) and to support it with NATO Force Integration Units (NFIU) in eight Eastern European NATO Nations changed the situation dramatically with the development of the NATO force structure, the establishment of multinational formations and a definition of the model for a forward presence on a rotational basis with an extended exercise program of some kind of "Connected Exercises."

Based on the experience gained with "NATO First" in supporting the NATO Force structure, many NATO partners such as Finland and Sweden started to use NATO tools in their processes for enhanced NATO Response Force (eNRF) and RAP implementation. These efforts included the deployment of eight NFIUs in a very short period in parallel and transforming the C2 system of Multinational Corps North-East in Poland and deploying a new Multinational Division South East $\mathrm{HQ}$ in Romania. To address this challenge, the report from the 7th Cycle NEDP project on "NATO 1st, Sharing Alliance Capabilities with Nations" internally

19 "Smarter Smart Defense: Multinational Cooperation Facilitated," NATO Executive Development Program (NEDP) Project Report (NCl Agency and NSPA, NATO HQ, 2014).

20 "Smart Defense: Five Years on - Making Smart Defense Even Smarter!" NEDP project report (Brussels: NATO HQ, NCl Agency, 2016).

${ }^{21}$ Customer Service Catalogue, Part I: Customer Handbook (NCl Agency, 2015).

22 "NATO First: Sharing Alliance Capabilities with Nations," NEDP project report $(\mathrm{NCl}$ Agency, 2016).

23 "NATO 1st Solution for NATO Force Structure" (NCl Agency), accessed October 29, 2018, https://www.ncia.nato.int/Documents/Agency publications/Brochure NATO 1st Solution for NATO Force structure_WEB.pdf.

${ }^{24}$ McChrystal, My Share of the Task. 
for $\mathrm{NClA}$, a program to support these various projects with different funding models, but similar requirements were established. ${ }^{25}$

With the decisions at the Warsaw Summit for the Forward Presence in Eastern Europe and its enhanced and tailored models, the need for more formal program management was evident to the leadership of the NClA and so a partnership model ${ }^{26}$ for this endeavor was explored.

\section{NATO/EU Readiness and Interoperability in Eastern Europe - C4ISR Perspective}

NATO agreed on a Readiness Initiative in $2018,{ }^{27}$ under the notion of The Four Thirties, that by 2020 the Allies would be able to have 30 mechanized battalions, 30 air squadrons, and 30 combat vessels ready within 30 days or less. This big change began in Wales in 2014 with the initiation of the Readiness Action Plan, followed by the Warsaw NATO agreement on Forward Presence in parallel with closer coordination with the EU on areas such as mobility, cyber defense, hybrid warfare response, and resilience at large. NATO has always been an alliance of interoperability between members but, with the Interoperability initiative at Wales Summit (2014), it has become a platform to boost interoperability with key partners as well, based on the experience of ISAF and other operations.

In this context, and based on experience going back to 2002 (more than 15 years of development) a framework is proposed for the (Communications \& Information) Program "Readiness and Interoperability (Cyber Resilience)" (PRI) with an initial focus on the Bucharest 9 countries (Bulgaria, Czech Republic, Estonia, Hungary, Latvia, Lithuania, Poland, Romania, Slovakia). These are nations that have moved from the Warsaw Pact to NATO and the EU in the last 20 years and form a potential framework of nations for rotational battle groups and other formations in the scope of Forward Presence as well as other related initiatives. These would include US troops under the Atlantic Resolve/European Defense Initiative, but would also include the further development of multinational formations in Eastern Europe, including the evolution of KFOR and Althea as key elements of multinational military presence in Southeast Europe.

Such a program would begin with the identification of the force structure in Eastern Europe. These might include different NFS elements, other multinational formations under NATO or EU initiatives (for example, in Southeast Europe, the HELBROC Battle Group comprising Greece, Romania, Bulgaria, Cyprus and with participation from Ukraine and even SEEBRIG, established in 1999 as an instrument for regional defense cooperation in SEE) and elements of the national force

25 "Initiative for NATO Forces Readiness and Interoperability Partnership (NRIP)," Enclosure 2 to NClA/DM/2016/02367 (NCl Agency, 2016).

26 "NATO 1st Solution (N1S) Concept: Partnership with Customers," Enclosure 3 to NCIA/DM/2016/02367, NCl Agency, 2016.

27 The SecGen, Mr. Stoltenberg, said in June 2018: "This Is not about setting up or deploying new forces, it is about boosting the readiness of existing forces." 
structures of the host countries to be included in such large scale interoperability and readiness endeavor.

Stakeholders in PRI would be the nations whose force structure elements are covered and leadership of the multinational formations addressed plus the strategic commands, respective NATO committees, boards, and related elements on the European defense side. Moreover, the $B 9$ (Bucharest cooperation) format can be seen as an excellent platform for transforming NATO-EU cooperation by introducing a new approach to modernizing the forces of the nine Nations, increasing their NATO/EU readiness and interoperability (including cyber resilience), and integrating them with the forward deployed forces of other NATO/EU nations on a rotational basis, as well as participation in any expeditionary or intervention forces of NATO or the EU.

Poland, Romania, and Bulgaria could, potentially, benefit most from effective and efficient rearmament and a new level of readiness and interoperability of the force structures in CEE. This would also be for both NATO and EU purposes, but, first of all, for deterrence and defense to the East and, possibly, the SouthEast through a real federation with NATO/EU systems. B9 is providing a solid basis for the development of PRI as a practical aspect of cooperation in both the NATO and EU context with the close support of NATO Communications and Information Agency for the C4ISR capabilities development and service provision.

There has been an effort on the Bulgarian side since 2014 to define a National Program called "Bulgaria in NATO and the European Defense" with focus on rearmament. It is now moving towards some real projects which have been approved by the Parliament. The most recent-Vision 2030-has civilian support and is a comprehensive and strategic approach to rearmament and close cooperation with B9 Allies. From a Bulgarian perspective, including Albania, Montenegro, and North Macedonia is of critical importance and, in cooperation with Greece, this will change the defense posture in the region. The next step will be to engage with Bosnia and Herzegovina, Kosovo, and Serbia.

Being both NATO and EU members, the Nations of $\mathrm{B} 9$ are in a position to harmonize their requirements and to use all available NATO, EU, and multinational/ regional instruments to build the best possible C4ISR/Cyber capabilities for their armed forces in the context of multinational NATO/EU force structures. In addition to B9, the involvement of Adriatic countries such as Albania, Croatia, Montenegro, Slovenia, and North Macedonia (soon to be a 30th member of NATO) plus some Black Sea candidates for NATO/EU membership, such as Ukraine and Georgia (and even Moldova) could be considered under the partnership arrangements.

In this context, a program of "Readiness and Interoperability" for B9+ nations with the participation of leading battle groups and/or rotating forces from other NATO nations in the region is a logical construct. The program could be supported by NCIA in the context of a "NATO First Solution" with customer funding (including available common funding from existing and future C4 Trust Funds). In the past, and certainly in the future, the main effort under the PRI will include a 
lot of case by case, but urgent and operations-related activities and exercise requests, anticipating rapid reaction.

NCIA did a study on external (non-common funded) customer-support with the Network Centric Operations Industrial Consortium (NCIOC) to define the most adequate model, based on the best practices from industry for meeting this challenge. This is a good basis for providing support to outside customers under PRI without interfering with the common funded programs.

Obviously, the C4ISR/Cyber domain is driving innovation, not only in the technology area but in all other aspects, including business models for cooperation and developing required institutions to make this effort a success for all. In this context, the discussions on NATO Allied Command Transformation (NCIOC-ACT) about the adoption of interoperability verification before the acquisition of goods and services are providing additional incentives for PRI. The Interoperability Verification Initiative could start ground-breaking projects to develop a new standard in procurement practice that examines enterprise-level interoperability for the Federated Mission Networking environment. This is expected to save billions of Euros for NATO, its members, and partners with obvious benefits for B9+ Nations.

So, there is now an opportunity to review C4ISR/Cyber related projects and programs in the B9+ countries in the context of implementing RAP/FP and Readiness Initiative/ Interoperability Initiative and to consolidate the work in the NATO/EU context for saving money. Perhaps more important will be the ability to achieve a high level of interoperability, security, and readiness of the C2 system on the Eastern Flank with the inclusion of regional countries with troop rotations involving members and partner nations. NATO $\mathrm{HQ}$, the strategic commands, NCIA could play a role, but ownership is for the B9 countries with the involvement of industry and research institutions for the transformational PRI. There will also be a benefit for European defense developments with PRI.

Since its establishment in 2012, the $\mathrm{NCl}$ Agency has, by merging the various five NATO C\&I agencies, had a declared initiative for the National Chief Information Officers $(\mathrm{CIO})$, together with $\mathrm{ACO}, \mathrm{ACT}$ and NATO $\mathrm{HQ}$ representatives of NFS, research institutions, and industry to define the most effective, efficient and cyber-resilient way to interoperability and readiness in the area of C\&l. Their, now traditional, annual $\mathrm{ClO}$ conferences ${ }^{28}$ paved the way to implementing the NATO First Solution and achieving interoperability and readiness in a secure environment by fast, easy, and affordable ways (NATO R\&I SAFE).

Defining PRI as the result of the NATO/EU led review of requirements with the active implementation of FMN compliant solutions in cooperation with industry and the NCIA as an executive/support agency will bring practical aspects of Interoperability and readiness to a new level in Central and Eastern Europe. $\mathrm{PRI}$ needs to be fully synchronized with all exercises involving forces in CEE with

${ }^{28}$ For information on each in the series of "Chief Information Officers" conferences see the website of the $\mathrm{NCl}$ Agency, https://www.ncia.nato.int. 
NATO/EU operations, missions, activities, and tasks for not just continuous improvement of interoperability and readiness, but also to enable them to provide a real contribution to deterrence and defense. In parallel, consideration should be given to extending PRI to all "new" NATO Nations in CEE as well as to define PRI Partners to support work with the partners in CEE (including Western Balkans and Black Sea region).

Conceptualization of the scope and Governance/Management of PRI could be done in the larger environment of Industry and NGO consultations, but real steps could be taken only by Nations or ACO/ACT related EU structures. Of course, existing models, implemented for the AMN/FMN environment as the Distributed Network of Battlelabs (DNBL) as an instrument to support the program, will also be used to shape the program.

\section{Education and Training as Major Tools for Interoperability. Implica- tions for the Western Balkans and the Black Sea Region}

When it comes to readiness and interoperability, especially of multinational formations, it is not just about the equipment but also about people and their education and training. This is the reason to consider the network of multinational formations in CEE as instruments to foster cooperation in the area of education and training, certification, and development of personnel. It is evident that for multinational formations, including on the tactical level (battalion battle groups, air squadrons, ships deignated for the Readiness initiative, for example), the operational language will be English, the procedures will be NATO-based, and C2 will require NATO First Solutions.

For these reasons, the synchronization of education and training programs for officers, non-commissioned officers, and even soldiers has to be achieved around NATO standards. Equally important is the experience from rotation in multinational units. The Partnership for Peace Consortium of Defense Academies and Security Studies Institutes, together with the NATO Defense Education Enhancement Program, is already providing a lot through their joint work on reference curricula in various fields. ${ }^{29}$ These curricula bring the Professional Military Education of NATO allies and their partners closer together, enhancing standardization and also improving intellectual interoperability. The same is true for the efforts of the European Security and Defense College, which is part of the European External Action Service. It has focused efforts to bring common standards to education and training in EU-wide professional military education. ${ }^{30}$

29 See "Generic Officer Professional Military Education - Reference Curriculum," "Cybersecurity - A Generic Reference Curriculum," and "Non-Commissioned Officer Professional Military Education - Reference Curriculum," all avialble on the NATO website, https://www.nato.int.

${ }^{30}$ European Security and Defense College (ESDC), "Standard Curricula," accessed October 29, 2018, https://eeas.europa.eu/topics/common-security-and-defense-policy-csdp/ 4369. 
While it is often important to distinguish between education and training, in this article the view is taken that they are mutually inclusive activities. Education and training, together with experience, are necessary for the complete development of military personnel. Interoperability in both education and training is the critical gateway to endow a nation's armed forces with the ability to live up to and to meet national security responsibilities in an international security environment where working closely with Allies and partners is crucial. Thus, the proposal to concentrate further efforts of NATO and the EU in the Western Balkans and the Black Sea region in order to meet the current security challenges via academic dialogue and interoperability in professional military education and training. This will provide a steady basis for delivering on Deterrence and Defense and for projecting stability in the regions.

\section{Conclusion: Regional Cooperation (SEDM/A5 and B9): Is Consolidation Possible?}

An analysis of the development of the NATO/EU presence in Central and Eastern Europe, especially through multinational formations-from KFOR to battle groups of eFP in Baltic states and Poland, the EU battle groups (as HELBROC in South-Eastern Europe) on the first level, followed by division/corps level HQs and up to NCS-provides an input to identify the requirements for interoperable C2 systems at a tactical level, directly connected to operational/ strategic level and respective training requirements for the personnel in these multinational formations.

Even more serious is the challenge to define the roadmap for the development of these multinational formations in Eastern Europe in a NATO/EU framework with the participation of the Western European and North American members of the Atlantic Alliance. It is important to stress that multi-nationality on a tactical level-in battalions, squadrons, and ships-is what matters most of all. This is because it is about the real use of NATO procedures on a daily basis, C2 systems, and the demonstration of solidarity. These tactical units, being multinational, will be a model for the national units of the same type or size but, being under multinational governance, $\mathrm{C} 2$ will maintain the readiness and interoperability required by the Readiness Initiative, and so they will have better chances to be committed for deployment without caveats.

Based on the large pool of multinational tactical units, it is much easier to nominate higher level multinational HQs for the management of training and readiness and for planning and $\mathrm{C} 2$ in case of activation. Such organizations will facilitate multinational projects for C4ISR interoperable systems and other equipment and/or armaments as well. These multinational projects could be managed by extended national agencies but maybe an even better option is to use NCIA/NSPA.

The last but not least is the organization for the education and training, covering all facets from individual to collective and from field to computer assistance. 
The main message in this article is that if NATO is to mature by consolidating the existing structures of multinational formations and develop a roadmap for its further development in CEE/SEE with a special focus on multinational C4ISR projects and joint education and training focused on interoperability and readiness, the landscape of security and defense could be changed dramatically. Real transformation in defense could take place in the region and, as a result, overall resilience will be improved.

Further research is required to develop the business case for a Program for Readiness and Interoperability, to define the governance and management model for the program, the technology roadmaps and specific requirements for education and training (including exercises), and for the implementation of a forward presence in CEE/SEE that will foster NATO-EU and regional cooperation.

\section{Disclaimer}

The views expressed are solely those of the author and do not represent official views of the PfP Consortium of Defense Academies and Security Studies Institutes, participating organizations, or the Consortium's editors.

\section{Acknowledgment}

Connections: The Quarterly Journal, Vol. 18, 2019 is supported by the United States government.

\section{About the Authors}

After 19 years in the military, Dr. Velziar Shalamanov followed by an academic career in the Academy of Sciences mixed with several tours of public service: Deputy Minister of Defense (1998-2001), Minister of Defense (2014) and Director Demand Management in the NATO's IT and Cyber Agency (2009-2017). Currently, he is focusing on the consolidation of the academic cyber capacity in Bulgaria. In parallel, he is engaged in politics and NGOs pursuing better positioning of Bulgaria in NATO and European defense, the information society and improvement of research governance.E-mail: shalamanov@acad.bg.

Mr. Pavel Anastasov has been heading the Unit for Strategic Policies and Analysis in the Cabinet of the President of the Republic of Bulgaria in the period 20122014. He served as deputy minister of defense in 2014. In the period 2014-2018 he has been working on Black Sea Security issues in the Political Affairs and Security Policy division at NATO HQ.

Dr. Georgi Tsvetkov is assistant professor at the "G.S. Rakovski" National Defense College in Sofia, covering various topics in the area of defense management, capability development and security policy. 